\title{
DYNAMICS OF HERITABILITY IN DIFFERENT CHARACTERS OF LETTUCE ${ }^{1}$
}

\author{
ALISSON HENRIQUE GAMA DE OLIVEIRA ${ }^{2}$, GABRIEL MASCARENHAS MACIEL ${ }^{2}$, ANA CAROLINA SILVA \\ SIQUIEROLI* ${ }^{3 *}$, JOSÉ MAGNO QUEIROZ LUZ ${ }^{2}$, ERNANI CLARETE DA SILVA ${ }^{4}$
}

\begin{abstract}
The lack of knowledge of the genetic parameters and the type of gene action results in difficulties to obtain varieties that combine agronomic and functional characteristics. The objective of this study was to determine the type of gene action associated with the contents of chlorophyll and agronomic characteristics in lettuce populations. The research was conducted at the Experimental Station of Vegetables, Monte Carmelo, Brazil. To perform the crosses and obtain the generations $\mathrm{P}_{1}, \mathrm{P}_{2}, \mathrm{~F}_{1}, \mathrm{~F}_{2}, \mathrm{Bc}_{1}$ and $\mathrm{Bc}_{2}$ the genotypes UFU-Albina\#2, UFU-Albina\#3, UFU-Lisa124\#2\#1, UFU-Crespa199\#1\#1 and UFU-Lisa217\#5\#2 were used as parents. The generations were evaluated for three characteristics: number of leaves, plant diameter and chlorophyll content. The parameters: genetic, phenotypic, environmental and additive variance, the dominance in $\mathrm{F}_{2}$, heritability in the broad and narrow-sense, the average degree of dominance based on averages, number of genes, the measure of the dominance deviations, additive effects and all interactions of 'additive $\mathrm{x}$ additive', 'additive $\mathrm{x}$ dominant' and 'dominant $\mathrm{x}$ dominant' type, were evaluated. Chlorophyll content was the most influenced by the environment. Plant diameter had the highest narrow-sense heritability for the cross UFU-Lisa-124\#2\#1 x UFU-Albina\#3 (82.1\%). The number of genes for the number of leaves varied from inconclusive to a minimum of 9 genes. The gene interactions for number of leaves were of overdominance type, while for plant diameter and for chlorophyll content the gene interactions were of partial dominance. The characteristics are suggested as being of polygenic or oligogenic nature.
\end{abstract}

Keywords: Lactuca sativa. Additive effects. Chlorophyll. Number of leaves. Plant diameter.

\section{DINÂMICA DA HERDABILIDADE EM DIFERENTES CARACTERES DE ALFACE}

RESUMO - O desconhecimento dos parâmetros genéticos e o tipo de ação gênica resultam em dificuldades na obtenção de variedades que combinam características agronômicas e funcionais. O objetivo deste estudo foi determinar o tipo de ação gênica envolvida com o conteúdo de clorofila e características agronômicas em populações de alface. A pesquisa foi realizada na Estação Experimental de Hortaliças, Monte Carmelo, Brasil. Para realizar os cruzamentos e obter as gerações $\mathrm{P}_{1}, \mathrm{P}_{2}, \mathrm{~F}_{1}, \mathrm{~F}_{2}, \mathrm{Bc}_{1}$ e $\mathrm{Bc}_{2}$, os genótipos UFU-Albina\#2, UFUAlbina\#3, UFU-Lisa124\#2\#1, UFU-Crespa199\#1 e UFU-Lisa217\#5\#2 foram usados como parentais. As gerações foram avaliadas para três características (número de folhas, diâmetro das plantas e teor de clorofila) e analisados os seguintes parâmetros: variância genética, ambiental, fenotípica, aditiva, dominância em $F_{2}$, herdabilidade no sentido amplo, herdabilidade no sentido restrito, grau médio de dominância baseado em médias, número de genes, medida dos desvios da dominância, medida dos efeitos aditivos, medida de todas interações do tipo aditiva $\mathrm{x}$ aditiva, aditiva $\mathrm{x}$ dominante e dominante $\mathrm{x}$ dominante. $\mathrm{O}$ teor de clorofila foi a característica mais influenciada pelo ambiente. O diâmetro de planta apresentou a maior herdabilidade no sentido restrito para o cruzamento UFU-Lisa-124\#2\#1 x UFU-Albina\#3 (82,1\%). O número de genes para a característica de número de folhas oscilou desde valores inconclusivos até um máximo de 9 genes. As interações gênicas para número de folhas demonstraram ser do tipo sobredominância enquanto que para diâmetro de plantas e teor de clorofila do tipo dominância parcial. Sugere-se que as características avaliadas são de natureza poligênica ou oligogênica.

Palavras-chave: Lactuca sativa. Efeitos aditivos. Clorofila. Número de folhas. Diâmetro da planta.

\footnotetext{
${ }^{*}$ Corresponding author

${ }^{1}$ Received for publication in $04 / 26 / 2020$; accepted in 03/08/2021.

Paper extracted from the master dissertation of the first author.

${ }^{2}$ Institute of Agricultural Sciences, Universidade Federal de Uberlândia, Monte Carmelo, MG, Brazil; agralisson@gmail.com - ORCID: 0000-0001-8502-8034, gabrielmaciel@ufu.br - ORCID: 0000-0002-3004-9134, jmagno@ufu.br - ORCID: 0000-0002-5712-7710.

${ }^{3}$ Institute of Biotechnology, Universidade Federal de Uberlândia, Monte Carmelo, MG, Brazil; carol@ufu.br - ORCID: 0000-0003-47131262 .

${ }^{4}$ Department of Agricultural Sciences, Universidade Federal de São João del-Rei, Sete Lagoas, MG, Brazil; clarete@ufsj.edu.br - ORCID: 0000-0001-7515-7588.
}

Rev. Caatinga, Mossoró, v. 34, n. 3, p. 514 - 526, jul. - set., 2021 


\section{INTRODUCTION}

Lettuce (Lactuca sativa L.) is the leafy green vegetable with the greatest economic importance in Brazil (GOMES et al., 2016, BRZEZINSKI et al., 2017).

To meet the growing demand for processed lettuce, there is a need to select several agronomic traits that are routinely evaluated in experiments of performance. Genotypes that have great number of leaves are preferred (SALA; COSTA, 2012; RESENDE et al., 2017). There are reports of commercial cultivars with number of leaves above 33 per plant (DIAMANTE et al., 2013). In contrast, plants with a diameter greater than $30 \mathrm{~cm}$ are not commercially interesting. Suinaga et al. (2013) reported that large plant diameters hinder transport, especially during the preparation of the plant in containers.

In addition to the agronomic variables of interest, it is also fundamental to obtaining biofortified plants; however, there are scarce results in the literature in this line. Among the various constituents that characterize biofortification, the carotenoid content is of great relevance in several species (MACHADO JUNIOR et al., 2017; OLIVEIRA et al., 2018; OLIVEIRA et al., 2019).

Additionally, there are reports of the association of carotenoids acting together with the increase of chlorophyll enabling the constancy of green color in leaves (TAIZ; ZEIGER, 2013). In fact, a positive correlation between carotenoid content and chlorophyll content, measured in an indirect way with the use of the SPAD index, has been observed (SILVA et al., 2014; CASSETARI et al., 2015; OLIVEIRA et al., 2019). High levels of chlorophyll potentiate the photosynthetic activity, which can also lead to increments related to agronomic characteristics (SILVA et al., 2014). Thus, the indirect selection of superior individuals for the characteristic of interest becomes possible using the chlorophyll content as a parameter.

Currently, there are available commercial cultivars of lettuce that combine good agronomic characteristics with great content of carotenoids. One of the barriers to improve such characteristic may be related to the limitation of information regarding the knowledge of parameters that govern the genetic inheritance of chlorophyll content and the main agronomic traits of interest in lettuce.

The understanding of the genetic bases involved in the expression of target characteristics is essential for the success of breeding programs (ANDRADE et al., 2010). Estimates of genetic parameters such as the magnitude of the heritability and the nature of the genes involved in the expression of the characteristics are of great importance to predict genetic gains and the potential of the population to be improved (CUSTÓDIO et al., 2012). Therefore, the estimates of genetic parameters and the mode of inheritance of such characteristics are fundamental to the establishment of the best breeding strategies (CORREA et al., 2012; BALDISSERA et al., 2014; LAVIOLA et al., 2014).

Thus, this study aimed to determine the type of gene action associated with the contents of chlorophyll and interesting agronomic characteristics in different populations of lettuce.

\section{MATERIAL AND METHODS}

The experiment was conducted from February 2017 to June 2018 at the Experimental Station of Vegetables, Monte Carmelo, MG, Brazil (18 $42^{\prime} 43.19^{\prime \prime} \mathrm{N}, 47^{\circ} 29^{\prime} 55.8^{\prime \prime} \mathrm{W}$, at $873 \mathrm{~m}$ of altitude).

The genetic material used consisted of five strains of lettuce (UFU-Albina\#2, UFU-Albina\#3, UFU-Lisa124\#2\#1, UFU-Crespa199\#1\#1, UFULisa217\#5\#2) (Table 1) obtained by six successive self-fertilizations after hybridization between the lettuce genotypes Belíssima and Uberlândia 10.000. The five strains (parent) used in this study were indexed in the database of BG $\alpha$ BIOFORT software (MACIEL et al., 2019), which stores information about more than 200 accessions of biofortified lettuce of the UFU.

Table 1. Leaf color, number of leaves, plant diameter and chlorophyll content of five lettuce strains used in this study to estimate the genetic parameters.

\begin{tabular}{lcccc}
\hline \multicolumn{1}{c}{ Genotype } & Leaf color & NL & PD $(\mathrm{cm})$ & Chlorophyll content \\
\hline UFU-Albina\#2 & Green & 12.22 & 18.50 & 17.35 \\
UFU-Albina\#3 & Green & 19.87 & 26.84 & 22.50 \\
UFU-Lisa124\#2\#1 & Green & 28.97 & 27.71 & 33.23 \\
UFU-Crespa199\#1\#1 & Purple & 51.52 & 30.13 & 43.02 \\
UFU-Lisa217\#5\#2 & Green & 31.03 & 22.66 & 38.68 \\
\hline
\end{tabular}

$\mathrm{NL}=$ number of leaves, $\mathrm{PD}=$ plant diameter; Chlorophyll content $=\mathrm{SPAD}$ index collected from $\mathrm{BG} \alpha \mathrm{BIOFORT}$ software (UFU). 
These genotypes are part of the germplasm bank of the Tropicalized Biofortified Lettuce Breeding Program. The criterion for selection of these five genotypes among more than 200 accessions registered was the greatest distance in magnitude (contrast) between the target characteristics of this research for studies of the estimates of the genetic parameter (number of leaves, plant diameter and chlorophyll content). To achieve success in studies of heritability, it is necessary to use contrasting parents regarding the characteristics studied (BALDISSERA et al., 2014).

On February 20 $0^{\text {th }}(2017)$, the selected genotypes were sown for further hybridization and production of the $F_{1}$ generation. The crosses were performed adopting the strains UFU-Albina\#2 and UFU-Albina\#3 as the male parent and UFULisa124\#2\#1, UFU-Crespa199\#1\#1 and UFULisa217\#5\#2 as the female parent.

The putative seeds from each cross $\left(\mathrm{F}_{1}\right)$ were sown on September $22^{\text {nd }}(2017)$, with subsequent identification of plants that exhibited hybrid vigor when compared with the characteristics of the parents. The advancement of generations of hybrid plants obtained by self-fertilization produced the seeds of the $\mathrm{F}_{2}$ generation and of the backcrosses. On March $23^{\text {rd }}(2018)$, the parents $\left(\mathrm{P}_{1}\right.$ and $\left.\mathrm{P}_{2}\right)$ were sown simultaneously and the generations $\mathrm{F}_{1}, \mathrm{~F}_{2}, \mathrm{Bc}_{1}$, and $\mathrm{Bc}_{2}$ referring to each direction of hybridization were used to obtain the lettuce populations (Table 2).

Table 2. Direction of crosses between the contrasting parents and number of plants evaluated in each generation in their respective crosses.

\begin{tabular}{lcccccc}
\hline \multirow{2}{*}{ Crosses } & \multicolumn{5}{c}{ Generations } \\
\cline { 2 - 7 } & $\mathrm{P}_{1}$ & $\mathrm{P}_{2}$ & $\mathrm{~F}_{1}$ & $\mathrm{~F}_{2}$ & $\mathrm{Bc}_{1}$ & $\mathrm{Bc}_{2}$ \\
\hline UFU-Lisa-124\#2\#1 x UFU-Albina\#2 & 60 & 40 & 20 & 312 & 23 & 32 \\
UFU-Lisa-217\#5\#2 x UFU-Albina\#2 & 60 & 38 & 20 & 323 & 17 & 28 \\
UFU-Lisa-124\#2\#1 x UFU-Albina\#3 & 62 & 40 & 20 & 340 & 20 & 28 \\
UFU-Crespa199\#1\#1 x UFU-Albina\#3 & 62 & 40 & 20 & 307 & 10 & 33 \\
UFU-Lisa-217\#5\#2 x UFU-Albina\#3 & 62 & 38 & 20 & 367 & 7 & 3 \\
\hline
\end{tabular}

The plants were grown under field conditions and planted at a $0.25 \times 0.25 \mathrm{~m}$ spacing. Genetic design analysis of segregating generations, and not the segregating genotypes $\left(\mathrm{P}_{1}, \mathrm{P}_{2}, \mathrm{~F}_{1}, \mathrm{~F}_{2}, \mathrm{Bc}_{1}\right.$ and $\mathrm{Bc}_{2}$ ) was used, and the number of plants was variable in each generation (Table 2).

After the plants reach commercial standard (65 days after sowing), the following variables were evaluated: i) Number of leaves: determined by manually counting the number of leaves with length equal to or greater than $5 \mathrm{~cm}$; ii) Plant diameter: plant diameter $(\mathrm{cm})$ was obtained by measuring the distance between the edges of the plants with the aid of a graduated ruler; and iii) Chlorophyll content: measured in leaf located in the middle of the lettuce plant with the aid of portable chlorophyll meter (Minolta SPAD-502 CFL1030).

Genetic-statistical analyses were performed using the program Genes v.2013.5.1 (CRUZ, 2013), and the following parameters were obtained: genetic variance in $\mathrm{F}_{2}\left(\sigma_{g}^{2}\right)$, environmental variance in $\mathrm{F}_{2}$ $\left(\sigma_{m}^{2}\right)$, phenotypic variance in $\mathrm{F}_{2}\left(\sigma_{f}^{2}\right)$, additive variance in $\mathrm{F}_{2}\left(\sigma_{a}^{2}\right)$, variance due to deviations of dominance in $\mathrm{F}_{2}\left(\sigma_{d}^{2}\right)$, broad-sense heritability $\left(h_{b}^{2}\right)$, narrow-sense heritability $\left(h_{n}^{2}\right)$, average degree of dominance based on averages (K), minimum number of genes $(\eta)$, average $(m)$ epistatic variance of the additive $\mathrm{x}$ additive type (aa), epistatic variance of the additive $\mathrm{x}$ dominant type (ad) and epistatic variance of the dominant $\mathrm{x}$ dominant type (dd), as the following expressions:

Genetic variance in $\mathrm{F}_{2}$ :

$$
\sigma_{\mathrm{g}\left(\mathrm{F}_{2}\right)}^{2}=\sigma_{\mathrm{f}\left(\mathrm{F}_{2}\right)}^{2}-\sigma_{\mathrm{m}\left(\mathrm{F}_{2}\right)}^{2}
$$

Environmental variance in $\mathrm{F}_{2}$ :

$$
\sigma_{\mathrm{e}\left(\mathrm{F}_{2}\right)}^{2}=\frac{\mathrm{VM}_{\mathrm{P}_{1}}+\mathrm{VM}_{\mathrm{P}_{2}}+2 \mathrm{VM}_{\mathrm{F}_{1}}}{4}
$$

Phenotypic variance in $\mathrm{F}_{2}$ :

$$
\sigma_{\mathrm{f}\left(\mathrm{F}_{2}\right)}^{2}=\sigma_{\mathrm{F}_{2}}^{2}
$$

Additive variance in $\mathrm{F}_{2}$ :

$$
\sigma_{\mathrm{a}}^{2}=\frac{1}{2} \mathrm{a}^{2}=2 \sigma_{\mathrm{g}\left(\mathrm{F}_{2}\right)}^{2}-\left[\sigma_{\mathrm{g}\left(\mathrm{BC}_{1}\right)}^{2}+\sigma_{\mathrm{g}\left(\mathrm{BC}_{2}\right)}^{2}\right]
$$

where:

$$
\begin{aligned}
& \sigma_{\mathrm{g}\left(\mathrm{BC}_{1}\right)}^{2}=\sigma_{\mathrm{f}\left(\mathrm{BC}_{1}\right)}^{2}-\sigma_{\mathrm{m}\left(\mathrm{BC}_{1}\right)}^{2} \\
& \sigma_{\mathrm{g}\left(\mathrm{BC}_{2}\right)}^{2}=\sigma_{\mathrm{f}\left(\mathrm{BC}_{2}\right)}^{2}-\sigma_{\mathrm{m}\left(\mathrm{BC}_{2}\right)}^{2}
\end{aligned}
$$


$\mathrm{F}_{2}$ :

Variance due to deviations of dominance in

$$
\sigma_{d}^{2}=\frac{1}{4} d^{2}=\sigma_{g\left(F_{2}\right)}^{2}-\sigma_{a}^{2}
$$

Broad-sense heritability:

$$
\mathrm{h}_{\mathrm{a}}^{2}=\frac{\sigma_{\mathrm{g}\left(\mathrm{F}_{2}\right)}^{2}}{\sigma_{\mathrm{f}\left(\mathrm{F}_{2}\right)}^{2}}=\frac{\sigma_{\mathrm{g}\left(\mathrm{F}_{2}\right)}^{2}}{\sigma_{\mathrm{g}\left(\mathrm{F}_{2}\right)}^{2}+\sigma_{\mathrm{m}\left(\mathrm{F}_{2}\right)}^{2}}
$$

Narrow-sense heritability:

$$
\mathrm{h}_{\mathrm{r}}^{2}=\frac{\sigma_{\mathrm{a}\left(\mathrm{F}_{2}\right)}^{2}}{\sigma_{\mathrm{f}\left(\mathrm{F}_{2}\right)}^{2}}=\frac{\sigma_{\mathrm{a}\left(\mathrm{F}_{2}\right)}^{2}}{\sigma_{\mathrm{a}\left(\mathrm{F}_{2}\right)}^{2}+\sigma_{\mathrm{d}\left(\mathrm{F}_{2}\right)}^{2}+\sigma_{\mathrm{m}\left(\mathrm{F}_{2}\right)}^{2}}
$$

Average degree of dominance based on averages:

$$
\mathrm{K}=\frac{2 \overline{\mathrm{F}_{1}}-\left(\overline{\mathrm{P}_{1}}+\overline{\mathrm{P}_{2}}\right)}{\overline{\mathrm{P}_{1}}-\overline{\mathrm{P}_{2}}}
$$

where: $\overline{\mathrm{F}_{1}}, \overline{\mathrm{P}_{1}}$ and $\overline{\mathrm{P}_{2}}$ are averages of the progenitors $\mathrm{F}_{1}, \mathrm{P}_{1}$ and $\mathrm{P}_{2}$, respectively.

Minimum number of genes involved in determining the character:

$$
\eta=\frac{R^{2}\left(1+0.5 K^{2}\right)}{8 \sigma_{g}^{2}}
$$

Where $\mathrm{R}$ is the amplitude between the averages of parents, or $\mathrm{R}=\mathrm{P}_{1}-\mathrm{P}_{2}$.

Estimation of effects:

$$
\begin{gathered}
\widehat{\mathrm{m}}=\frac{1}{2} \overline{\mathrm{P}}_{1}+\frac{1}{2} \overline{\mathrm{P}}_{2}+4 \overline{\mathrm{F}}_{2}-2 \overline{\mathrm{BC}}_{1}-2 \overline{\mathrm{BC}}_{2} \\
\hat{\mathrm{a}}=\frac{1}{2} \overline{\mathrm{P}}_{1}+\frac{1}{2} \overline{\mathrm{P}}_{2} \\
\widehat{\mathrm{d}}=-\frac{3}{2} \overline{\mathrm{P}}_{1}-\frac{3}{2} \overline{\mathrm{P}}_{2}-\overline{\mathrm{F}}_{1}-8 \overline{\mathrm{F}}_{2}+6 \overline{\mathrm{BC}}_{1}-6 \overline{\mathrm{BC}}_{2} \\
\widehat{\mathrm{aa}}=-4 \overline{\mathrm{F}}_{2}+2 \overline{\mathrm{BC}}_{1}+2 \overline{\mathrm{BC}}_{2} \\
\widehat{\mathrm{ad}}=-\overline{\mathrm{P}}_{1}+\overline{\mathrm{P}}_{2}+2 \overline{\mathrm{BC}}_{1}-2 \overline{\mathrm{BC}}_{2} \\
\widehat{\mathrm{dd}}=\overline{\mathrm{P}}_{1}+\overline{\mathrm{P}}_{2}+2 \overline{\mathrm{F}}_{1}+4 \overline{\mathrm{F}}_{2}-4 \overline{\mathrm{BC}}_{1}-4 \overline{\mathrm{BC}}_{2}
\end{gathered}
$$

The relative superiority (RS) between the parents $\left(\mathrm{P}_{1}\right.$ versus $\left.\mathrm{P}_{2}\right)$ involved in the different hybridizations of the study were calculated (UFULisa-124\#2\#1 x UFU-Albina\#2, UFU-Lisa-217\#5\#2 x UFU-Albina\#2, UFU-Lisa-124\#2\#1 x UFUAlbina\#3, UFU-Crespa199\#1\#1 x UFU-Albina\#3, and UFU-Lisa-217\#5\#2 x UFU-Albina\#3). For the calculation, the following expression was used:

$$
\% \text { relative }=[(\mathrm{C} 1 \div \mathrm{C} 2)-1] \times 100
$$

Where: \%relative is equivalent to the percentage difference of the response variables (number of leaves, plant diameter and chlorophyll content); $\mathrm{C}_{1}=$ corresponds to $\overline{\mathrm{P}_{2}}$ (superior) and $\mathrm{C}_{2}=$ corresponds to generations $\overline{\mathrm{P}}_{1}, \overline{\mathrm{F}}_{1}, \overline{\mathrm{F}}_{2}, \overline{\mathrm{BC}}_{1}$ and $\overline{\mathrm{BC}}_{2}$.

\section{RESULTS AND DISCUSSION}

The estimation of genetic parameters should be carried out compulsorily involving contrasting parental target for the characteristic in the study (BALDISSERA et al., 2014). This item was confirmed by comparing $\overline{\mathrm{P}_{1}}$ versus $\overline{\mathrm{P}_{2}}$ in all crosses, allowing studies with greater accuracy (Table 3).

Additionally, the relative superiority (\%) was calculated by comparing the average of $\overline{\mathrm{P}_{2}}$ (superior) to that of the other generations $\overline{\mathrm{P}}_{1}, \overline{\mathrm{F}}_{1}, \overline{\mathrm{F}}_{2}, \overline{\mathrm{BC}}_{1}$ and $\overline{\mathrm{BC}}_{2}$ (Table 3 ). For chlorophyll content, all hybridizations UFU-Lisa-217\#5\#2 $\mathrm{x}$ UFU-Albina\#2, UFU-Lisa-124\#2\#1 x UFUAlbina\#2, UFU-Lisa-217\#5\#2 x UFU-Albina\#3, UFU-Lisa-124\#2\#1 x UFU-Albina\#3, and UFUCrespa199\#1\#1 x UFU-Albina\#3, showed wide RS\% in comparison to the average of the inferior parent $\overline{\mathrm{P}_{1}}$ with amplitude of $75.2 \%$ (minimum value 47.7 and maximum value $122.9 \%$ ).

Despite the existence of heterosis in all hybridizations, there was no heterobeltiosis for chlorophyll content in UFU-Lisa-217\#5\#2 x UFUAlbina\#3 and UFU-Lisa-124\#2\#1 x UFU-Albina\#3. Regarding plant diameter, an amplitude of $65.4 \%$ of the relative superiority, heterosis and heterobeltiosis was observed in all hybridizations. Greater amplitude of relative superiority was found for number of leaves $(145.6 \%)$ and heterosis in all hybridizations.

In contrast, there was heterobeltiosis only in the hybridizations UFU-Lisa-217\#5\#2 $x$ UFUAlbina\#3 and UFU-Crespa199\#1\#1 x UFUAlbina\#3. As it is an autogamous and cleistogamous species, hybrid seeds of L. sativa are obtained manually via cross-pollination, making commercial seed production unfeasible (AZEVEDO et al., 2013). However, it is important to emphasize that the success of breeding programs depends on the existence of genetic variability, contrasting parents and the correct choice of parents (BENIN et al., 
2002; BERTAN et al., 2006; BORÉM; MIRANDA, 2009). It was possible to observe that for the three characteristics evaluated (chlorophyll content, plant diameter and number of leaves), there was an important amplitude, heterosis and heterobeltiosis indicative of better hybridizations to support breeding programs.

Table 3. Estimates of genetic parameters of agronomic traits and relative superiority of the average of the superior parent $\left(\overline{\mathrm{P}}_{2}\right)$ in relation to the averages of in populations originated $\overline{\mathrm{P}}_{1}, \overline{\mathrm{F}}_{1}, \overline{\mathrm{F}}_{2}, \overline{\mathrm{BC}}_{1}$ and $\overline{\mathrm{BC}}_{2}$ from five crosses between Lactuca sativa and respective parents.

\begin{tabular}{|c|c|c|c|c|c|c|}
\hline Parameters & Chlorop. content & $\mathrm{RS}(\%)$ & Plant diameter & $\mathrm{RS}(\%)$ & $\begin{array}{c}\text { Number of } \\
\text { leaves }\end{array}$ & $\mathrm{RS}(\%)$ \\
\hline & \multicolumn{6}{|c|}{ UFU-Lisa-217\#5\#2 x UFU-Albina\#2 } \\
\hline $\bar{x} \mathrm{P}_{1}$ & 17.35 & 122.9 & 18.50 & 22.5 & 12.22 & 153.9 \\
\hline $\bar{x} \mathrm{P}_{2}$ & 38.68 & & 22.66 & & 31.03 & \\
\hline $\bar{x} \mathrm{~F}_{1}$ & 34.03 & 13.7 & 24.00 & -5.6 & 28.75 & 7.9 \\
\hline $\bar{x} \mathrm{~F}_{2}$ & 31.70 & 22.0 & 25.24 & -10.2 & 24.06 & 29.0 \\
\hline $\bar{x} \mathrm{Bc}_{1}$ & 21.28 & 81.8 & 20.91 & 8.4 & 17.35 & 78.8 \\
\hline $\bar{x} \mathrm{Bc}_{2}$ & 33.67 & 14.9 & 22.80 & -0.6 & 30.14 & 3.0 \\
\hline$\sigma_{\mathrm{g}}^{2}$ & 19.25 & & 15.96 & & 26.68 & \\
\hline$\sigma_{\mathrm{e}}^{2}$ & 32.69 & & 11.42 & & 23.16 & \\
\hline$\sigma_{f}^{2}$ & 51.95 & & 27.38 & & 49.84 & \\
\hline$\sigma_{\mathrm{a}}^{2}$ & 16.13 & & 30.23 & & 17.60 & \\
\hline$\sigma_{\mathrm{d}}^{2}$ & 3.12 & & -14.27 & & 9.08 & \\
\hline $\mathrm{h}_{a}^{2}$ & 37.07 & & 58.30 & & 53.53 & \\
\hline $\mathrm{h}_{\mathrm{r}}^{2}$ & 31.05 & & 110.44 & & 35.31 & \\
\hline $\mathrm{K}$ & -0.56 & & -1.64 & & -0.76 & \\
\hline$\eta$ & 13.34 & & 3.24 & & 9.20 & \\
\hline \multirow[t]{2}{*}{ TS } & $\mathrm{S}$ & & $\mathrm{S}$ & & $\mathrm{N}$ & \\
\hline & \multicolumn{6}{|c|}{ UFU-Lisa-124\#2\#1 x UFU-Albina\#2 } \\
\hline $\bar{x} \mathrm{P}_{1}$ & 17.35 & 91.5 & 18.50 & 49.8 & 12.22 & 137.1 \\
\hline $\bar{x} \mathrm{P}_{2}$ & 33.23 & & 27.71 & & 28.97 & \\
\hline $\bar{x} \mathrm{~F}_{1}$ & 32.44 & 2.4 & 25.61 & 8.2 & 22.30 & 29.9 \\
\hline $\bar{x} \mathrm{~F}_{2}$ & 29.15 & 14.0 & 21.24 & 30.5 & 16.28 & 77.9 \\
\hline $\bar{x} \mathrm{Bc}_{1}$ & 21.12 & 57.3 & 20.24 & 36.9 & 19.35 & 49.7 \\
\hline $\bar{x} \mathrm{Bc}_{2}$ & 32.35 & 2.7 & 29.84 & -7.1 & 29.50 & -1.8 \\
\hline$\sigma_{\mathrm{g}}^{2}$ & 1.58 & & 12.53 & & 16.76 & \\
\hline$\sigma_{\mathrm{e}}^{2}$ & 43.61 & & 14.28 & & 16.85 & \\
\hline$\sigma_{f}^{2}$ & 45.20 & & 26.81 & & 33.61 & \\
\hline$\sigma_{\mathrm{a}}^{2}$ & 62.26 & & 17.05 & & 23.94 & \\
\hline$\sigma_{\mathrm{d}}^{2}$ & -60.67 & & -4.52 & & -7.18 & \\
\hline $\mathrm{h}_{a}^{2}$ & 3.51 & & 46.72 & & 49.86 & \\
\hline $\mathrm{h}_{\mathrm{r}}^{2}$ & 137.74 & & 63.60 & & 71.22 & \\
\hline $\mathrm{K}$ & -0.90 & & -0.54 & & -0.20 & \\
\hline$\eta$ & 2.63 & & 6.29 & & 5.02 & \\
\hline TS & $\mathrm{S}$ & & $\mathrm{N}$ & & $\mathrm{N}$ & \\
\hline
\end{tabular}

$\sigma_{\mathrm{g}}^{2}=$ genotypic variance in $\mathrm{F}_{2} ; \sigma_{\mathrm{e}}^{2}=$ environmental variance in $\mathrm{F}_{2} ; \sigma_{f}^{2}=$ phenotypic variance in $\mathrm{F}_{2} ; \sigma_{\mathrm{a}}^{2}=$ additive variance in $\mathrm{F}_{2} ; \sigma_{\mathrm{d}}^{2}=$ variance due to deviations of dominance; $\mathrm{h}_{a}^{2}=$ broad-sense heritability; $\mathrm{h}_{\mathrm{r}}^{2}=$ narrow-sense heritability; $\mathrm{k}=$ average degree of dominance based on averages; $\eta=$ minimum number of genes involved in the expression of the character; TS $=$ transgressive segregation; Chlorop. content $=$ chlorophyll content; $\mathrm{RS}=$ relative superiority (\%). 
A. H. G. OLIVEIRA et al.

Table 3. Continuation.

\begin{tabular}{|c|c|c|c|c|c|c|}
\hline Parameters & Chlorop. content & $\mathrm{RS}(\%)$ & Plant diameter & $\mathrm{RS}(\%)$ & $\begin{array}{c}\text { Number of } \\
\text { leaves }\end{array}$ & $\mathrm{RS}(\%)$ \\
\hline \multicolumn{7}{|c|}{ UFU-Lisa-217\#5\#2 x UFU-Albina\#3 } \\
\hline $\bar{x} \mathrm{P}_{1}$ & 22.50 & 71.9 & 26.84 & -15.6 & 19.87 & 56.2 \\
\hline $\bar{x} \mathrm{P}_{2}$ & 38.68 & & 22.66 & & 31.03 & \\
\hline $\bar{x} \mathrm{~F}_{1}$ & 39.62 & -2.4 & 28.01 & -19.1 & 37.45 & -17.1 \\
\hline $\bar{x} \mathrm{~F}_{2}$ & 35.75 & 8.2 & 28.08 & -19.3 & 27.88 & 11.3 \\
\hline $\bar{x} \mathrm{Bc}_{1}$ & 31.06 & 24.5 & 31.21 & -27.4 & 24.57 & 26.3 \\
\hline $\bar{x} \mathrm{Bc}_{2}$ & 26.87 & 44.0 & 28.13 & -19.4 & 30.00 & 3.4 \\
\hline$\sigma_{\mathrm{g}}^{2}$ & 13.53 & & 16.63 & & 31.91 & \\
\hline$\sigma_{\mathrm{e}}^{2}$ & 37.76 & & 10.50 & & 19.62 & \\
\hline$\sigma_{f}^{2}$ & 51.29 & & 27.13 & & 51.34 & \\
\hline$\sigma_{\mathrm{a}}^{2}$ & -164.58 & & 9.66 & & 83.45 & \\
\hline$\sigma_{\mathrm{d}}^{2}$ & 178.12 & & 6.97 & & -51.54 & \\
\hline $\mathrm{h}_{a}^{2}$ & 26.39 & & 61.29 & & 61.92 & \\
\hline $\mathrm{h}_{\mathrm{r}}^{2}$ & -320.86 & & 35.60 & & 161.93 & \\
\hline $\mathrm{K}$ & -1.12 & & 1.56 & & -2.15 & \\
\hline$\eta$ & -1.17 & & 22.18 & & 2.40 & \\
\hline \multirow[t]{2}{*}{ TS } & $\mathrm{S}$ & & $\mathrm{S}$ & & $\mathrm{S}$ & \\
\hline & \multicolumn{6}{|c|}{ UFU-Lisa-124\#2\#1 x UFU-Albina\#3 } \\
\hline $\bar{x} \mathrm{P}_{1}$ & 22.50 & 47.7 & 26.84 & 3.2 & 19.87 & 45.8 \\
\hline $\bar{x} \mathrm{P}_{2}$ & 33.23 & & 27.71 & & 28.97 & \\
\hline $\bar{x} \mathrm{~F}_{1}$ & 33.98 & -2.2 & 30.24 & -8.4 & 28.35 & 2.2 \\
\hline $\bar{x} \mathrm{~F}_{2}$ & 29.32 & 13.3 & 26.47 & 4.7 & 23.19 & 24.9 \\
\hline $\bar{x} \mathrm{Bc}_{1}$ & 38.62 & -14.0 & 29.21 & -5.1 & 23.40 & 23.8 \\
\hline $\bar{x} \mathrm{Bc}_{2}$ & 33.68 & -1.3 & 31.25 & -11.3 & 32.64 & -11.2 \\
\hline$\sigma_{\mathrm{g}}^{2}$ & -1.85 & & 15.00 & & 14.87 & \\
\hline$\sigma_{\mathrm{e}}^{2}$ & 46.57 & & 16.68 & & 27.55 & \\
\hline$\sigma_{f}^{2}$ & 44.73 & & 31.68 & & 42.42 & \\
\hline$\sigma_{\mathrm{a}}^{2}$ & -3741.63 & & 8.65 & & 34.85 & \\
\hline$\sigma_{\mathrm{d}}^{2}$ & 3789.78 & & 6.34 & & -19.98 & \\
\hline $\mathrm{h}_{a}^{2}$ & -4.13 & & 47.34 & & 35.05 & \\
\hline $\mathrm{h}_{\mathrm{r}}^{2}$ & -8365.17 & & 27.32 & & 82.16 & \\
\hline $\mathrm{K}$ & -1.14 & & -6.77 & & -0.86 & \\
\hline$\eta$ & -0.07 & & 18 & & 4.91 & \\
\hline \multirow[t]{2}{*}{ TS } & $\mathrm{S}$ & & $\mathrm{S}$ & & $\mathrm{S}$ & \\
\hline & \multicolumn{6}{|c|}{ UFU-Crespa199\#1\#1 x UFU-Albina\#3 } \\
\hline $\bar{x} \mathrm{P}_{1}$ & 22.50 & 91.2 & 26.84 & 12.3 & 19.87 & 8.3 \\
\hline $\bar{x} \mathrm{P}_{2}$ & 43.02 & & 30.13 & & 21.52 & \\
\hline $\bar{x} \mathrm{~F}_{1}$ & 41.11 & 4.6 & 34.49 & -12.6 & 25.70 & -16.3 \\
\hline $\bar{x} \mathrm{~F}_{2}$ & 40.10 & 7.3 & 25.61 & 17.6 & 18.04 & 19.3 \\
\hline $\bar{x} \mathrm{Bc}_{1}$ & 35.93 & 19.7 & 32.62 & -7.6 & 26.10 & -17.5 \\
\hline $\bar{x} \mathrm{Bc}_{2}$ & 43.02 & 0.0 & 30.61 & -1.6 & 22.64 & -4.9 \\
\hline$\sigma_{\mathrm{g}}^{2}$ & 572.09 & & 18.91 & & 21.93 & \\
\hline$\sigma_{\mathrm{e}}^{2}$ & 65.84 & & 18.33 & & 11.59 & \\
\hline$\sigma_{f}^{2}$ & 637.93 & & 37.24 & & 33.53 & \\
\hline
\end{tabular}

$\sigma_{\mathrm{g}}^{2}=$ genotypic variance in $\mathrm{F}_{2} ; \sigma_{\mathrm{e}}^{2}=$ environmental variance in $\mathrm{F}_{2} ; \sigma_{f}^{2}=$ phenotypic variance in $\mathrm{F}_{2} ; \sigma_{\mathrm{a}}^{2}=$ additive variance in $\mathrm{F}_{2} ; \sigma_{\mathrm{d}}^{2}=$ variance due to deviations of dominance; $\mathrm{h}_{a}^{2}=$ broad-sense heritability; $\mathrm{h}_{\mathrm{r}}^{2}=$ narrow-sense heritability; $\mathrm{k}=$ average degree of dominance based on averages; $\eta=$ minimum number of genes involved in the expression of the character; TS $=$ transgressive segregation; Chlorop. content $=$ chlorophyll content; RS = relative superiority $(\%)$. 
A. H. G. OLIVEIRA et al.

Table 3. Continuation.

\begin{tabular}{|c|c|c|c|c|c|c|}
\hline Parameters & Chlorop. content & $\mathrm{RS}(\%)$ & Plant diameter & $\mathrm{RS}(\%)$ & $\begin{array}{c}\text { Number of } \\
\text { leaves }\end{array}$ & $\mathrm{RS}(\%)$ \\
\hline & \multicolumn{6}{|c|}{ UFU-Crespa199\#1\#1 x UFU-Albina\#3 } \\
\hline$\overline{\sigma_{\mathrm{a}}^{2}}$ & 1129.05 & & 13.55 & & -4.73 & \\
\hline$\sigma_{\mathrm{d}}^{2}$ & -556.96 & & 5.36 & & 26.67 & \\
\hline $\mathrm{h}_{a}^{2}$ & 89.68 & & 50.77 & & 65.42 & \\
\hline $\mathrm{h}_{\mathrm{r}}^{2}$ & 176.99 & & 36.39 & & -14.12 & \\
\hline $\mathrm{K}$ & -0.81 & & -3.65 & & -6.05 & \\
\hline$\eta$ & 21.85 & & 10.35 & & -32.34 & \\
\hline TS & $\mathrm{S}$ & & $\mathrm{S}$ & & S & \\
\hline
\end{tabular}

$\sigma_{\mathrm{g}}^{2}=$ genotypic variance in $\mathrm{F}_{2} ; \sigma_{\mathrm{e}}^{2}=$ environmental variance in $\mathrm{F}_{2} ; \sigma_{f}^{2}=$ phenotypic variance in $\mathrm{F}_{2} ; \sigma_{\mathrm{a}}^{2}=$ additive variance in $\mathrm{F}_{2} ; \sigma_{\mathrm{d}}^{2}=$ variance due to deviations of dominance; $\mathrm{h}_{a}^{2}=$ broad-sense heritability; $\mathrm{h}_{\mathrm{r}}^{2}=$ narrow-sense heritability; $\mathrm{k}=$ average degree of dominance based on averages; $\eta=$ minimum number of genes involved in the expression of the character; TS $=$ transgressive segregation; Chlorop. content $=$ chlorophyll content; RS $=$ relative superiority $(\%)$.

The transgressive segregation in this study was noticeable for all variables in the crosses UFULisa-124\#2\#1 x UFU-Albina\#3, UFUCrespa199\#1\#1 x Albina\#3 and UFU-Lisa-217\#5\#2 $x$ UFU-Albina\#3, while in the cross UFU-Lisa$217 \# 5 \# 2 \times$ UFU-Albina\#2 the segregation was not observed for number of leaves, and for the cross UFU-Lisa-124\#2\#1 x UFU-Albina\#3 the transgressive segregation was not observed for plant diameter and number of leaves.

With regard to estimates of genetic variances $\left(\sigma_{\mathrm{g}}^{2}\right)$, environmental variances $\left(\sigma_{\mathrm{e}}^{2}\right)$ and phenotypic variance $\left(\sigma_{\mathrm{f}}^{2}\right)$, the characteristic chlorophyll content (SPAD) was highly influenced by the environment, with the exception of the cross UFU-Crespa199\#1\#1 $x$ UFU-Albina\#3, which had genetic variance greater than the environmental variance (572.09 and 65.84, respectively).

The number of leaves and plant diameter had values of genetic variance ranging from 14.87 to 31.91 and from 12.53 to 18.91 , respectively, being greater than or close to the values of the environmental variance. Souza et al. (2008) found magnitudes of $\left(\sigma_{\mathrm{g}}^{2}\right)$ lower than those found in the present study. Higher magnitudes of genetic variances when compared to environmental variances generally lead to great possibilities of genetic gains with the proper process of selection (OLIVEIRA et al., 2015).

The results for plant diameter indicated that the additive variance is responsible for the largest fraction of genetic variance in all five groups of crosses evaluated. Similarly, for the number of leaves in the crosses UFU-Lisa-217\#5\#2 x UFUAlbina\#2, UFU-Lisa-124\#2\#1 x UFU-Albina\#2, UFU-Lisa-217\#5\#2 $\mathrm{x}$ Albina\#3 and UFU-Lisa124\#2\#1 $x$ UFU-Albina\#3 the additive variance explains great part of the genetic variance $\left(\sigma_{\mathrm{a}}^{2}=\right.$ $17.60 ; 23.94 ; 34.85$ and 9.66 , respectively), with the exception of the cross UFU-Crespa199\#1\#1 x UFUAlbina\#3, which showed different performance, where the magnitude of the genetic effect $\left(\sigma_{\mathrm{g}}^{2}=\right.$ 21.93) was due to variance attributed to deviations of dominance $\left(\sigma_{\mathrm{d}}^{2}=26.67\right)$.

In this way, the variables plant diameter for all the populations evaluated and number of leaves with the exception of the crosses UFUCrespa199\#1\#1 x UFU-Albina\#3 tend to have a great probability of being transferred and laid in homozygotic individuals in the following generations. The chlorophyll content in this study proved to be highly influenced by the environment assessed.

The estimates of narrow-sense heritability for number of leaves showed medium values, except for the crosses UFU-Lisa-124\#2\#1 x UFU-Albina\#3 and UFU-Lisa-217\#5\#2 x UFU-Albina\#3, in which the heritability was considered high $\left(\mathrm{h}_{\mathrm{r}}^{2}=82.16\right.$ and 161.63, respectively). This result is similar to those found by Souza et al. (2008), who evaluated progenies derived from the cross Regina $\mathrm{x}$ Tinto $\mathrm{x}$ Verdinha $\left(\mathrm{h}_{\mathrm{r}}^{2}=83.99 \%\right)$.

The chlorophyll content (SPAD) showed marked discrepancy between the heritability among the different populations, where the crosses UFULisa-217\#5\#2 $x$ UFU-Albina\#3 and UFU-Lisa124\#2\#1 x UFU-Albina\#3 had negative estimates. According to Blank et al. (2010), the heritability estimate is not an intrinsic value of the characteristic, varying among genotypes, environments and sites, a performance that is evident in the present study.

The estimates of the average degree of dominance based on averages indicated that there was predominantly gene action of overdominance type for the variable number of leaves. For chlorophyll content and plant diameter, there was a predominance of action of partial dominance.

The estimate of the number of genes that rule the chlorophyll content and the number of leaves have fluctuated from inconclusive (negative values) to a maximum of 21 and 9 genes, respectively. The characteristic plant diameter had to be governed by a 
minimum of 4 genes in the cross UFU-Lisa-217\#5\#2 $x$ UFU-Albina\#2 and a maximum of 22 genes in the cross UFU-Lisa-217\#5\#2 x UFU-Albina\#3.

The values obtained in the present study are consistent with the premise mentioned by Cruz, Regazzi and Carneiro (2012), who suggest that the estimated values should not be taken as absolute, due to the assumptions on which the estimation method is based. Thus, the estimate is more important as indicative of the character being of monogenic or polygenic nature. In the present study, there was an indication that the three traits evaluated (number of leaves, plant diameter and chlorophyll content) are of polygenic or oligogenic nature. In fact, when analyzing the estimates of genetic parameters from hybridization, Oliveira et al. (2019) observed similar results. Indication of polygenic or oligogenic inheritance was verified for the characteristics number of leaves and plant diameter. It is worth mentioning that in the present study, five hybridizations were evaluated, making it possible to verify the magnitude of the dynamics between the genetic components capable of providing the breeder with more accurate results.

In Table 4, the estimates of genetic parameters obtained in the complete model are presented. The additive effect was not significant by the $t$-test at $5 \%$ probability for all evaluated traits, except for plant diameter for the cross UFU-Lisa217\#5\#2 x UFU-Albina\#3. The deviations of dominance (D) of this character were not significant only for the cross UFU-Albina\#3 x UFU-Lisa217\#5\#2.

For the variables content of chlorophyll (SPAD), plant diameter, and number of leaves, the epistatic interactions of the additive $\mathrm{x}$ dominant (ad) type were not significant only in the cross UFU-Lisa$124 \# 2 \# 1$ x UFU-Albina\#2; the interactions of the dominant $\mathrm{x}$ dominant $(\mathrm{dd})$ type were significant for plant diameter except for the cross UFU-Lisa$217 \# 5 \# 2 \times$ UFU-Albina\#3. Also, the additive effect and dominance are involved in the expression of the chlorophyll content (SPAD) characteristic and were predominant in crosses involving the parent UFUAlbina\#3, since the epistatic effects were not significant.

Table 4. Estimates of the genetic parameters of the agronomic characteristics in the complete model (CM) and additivedominant model (ADM) in populations originated from five crosses between Lactuca sativa and parents.

\begin{tabular}{|c|c|c|c|c|c|c|}
\hline \multirow{2}{*}{ Parameters } & \multicolumn{2}{|c|}{ Chlorop. content } & \multicolumn{2}{|c|}{ Plant diameter } & \multicolumn{2}{|c|}{ Number of leaves } \\
\hline & $\mathrm{CM}$ & ADM & $\mathrm{CM}$ & ADM & $\mathrm{CM}$ & $\mathrm{ADM}$ \\
\hline \multicolumn{7}{|c|}{ UFU-Lisa-217\#5\#2 x UFU-Albina\#2 } \\
\hline $\mathrm{m}$ & $44.90 *$ & $27.97^{*}$ & $34.12 *$ & $21.39^{*}$ & $22.89^{*}$ & $21.53^{*}$ \\
\hline a & $-10.67 \mathrm{~ns}$ & $-10.57 \mathrm{~ns}$ & $-2.08 \mathrm{~ns}$ & $-2.07 \mathrm{~ns}$ & $-9.40 \mathrm{~ns}$ & $-9.44 n s$ \\
\hline $\mathrm{d}$ & $-41.94 n s$ & $6.23 *$ & $-25.39 n s$ & $4.73 *$ & $-1.16 \mathrm{~ns}$ & $28.75^{*}$ \\
\hline aa & $-16.88 \mathrm{~ns}$ & - & $-.13 .54 \mathrm{~ns}$ & - & $-1.27 \mathrm{~ns}$ & - \\
\hline $\mathrm{ad}$ & $-3.46 \mathrm{~ns}$ & - & $0.38 \mathrm{~ns}$ & - & $-6.77 \mathrm{~ns}$ & - \\
\hline $\mathrm{dd}$ & $31.07 *$ & - & $15.27 *$ & - & $7.02 \mathrm{~ns}$ & - \\
\hline \multicolumn{7}{|c|}{ UFU-Lisa-124\#2\#1 x UFU-Albina\#2 } \\
\hline $\mathrm{m}$ & $34.94 *$ & $25.42 *$ & $7.92 *$ & $22.59^{*}$ & $1.84 \mathrm{~ns}$ & $20.19^{*}$ \\
\hline a & $-7.94 \mathrm{~ns}$ & $-8.42 \mathrm{~ns}$ & $-4.61 \mathrm{~ns}$ & $-5.25 \mathrm{~ns}$ & $-8.38 \mathrm{~ns}$ & $-8.68 n s$ \\
\hline $\mathrm{d}$ & $-20.67 n s$ & $5.88 *$ & $35.61 *$ & $0.37 \mathrm{~ns}$ & $37.29 *$ & $-3.71 \mathrm{~ns}$ \\
\hline aa & $-9.64 n s$ & - & $15.19^{*}$ & - & $18.74 *$ & - \\
\hline $\mathrm{ad}$ & $-6.57 \mathrm{~ns}$ & - & $-9.99 \mathrm{~ns}$ & - & $-17.37 \mathrm{~ns}$ & - \\
\hline $\mathrm{dd}$ & $18.17 *$ & - & $-17.92 \mathrm{~ns}$ & - & $-16.83 n s$ & - \\
\hline \multicolumn{7}{|c|}{ UFU-Lisa-217\#5\#2 x Albina\#3 } \\
\hline $\mathrm{m}$ & $57.74 *$ & $30.76^{*}$ & $18.38^{*}$ & $25.30^{*}$ & $27.81 *$ & $23.86^{*}$ \\
\hline $\mathrm{a}$ & $-8.10 \mathrm{~ns}$ & $-8.13 n s$ & $2.09 *$ & $1.93 *$ & $-5.58 \mathrm{~ns}$ & $-4.10 \mathrm{~ns}$ \\
\hline $\mathrm{d}$ & $69.85 \mathrm{~ns}$ & $9.67 \mathrm{~ns}$ & $29.16 \mathrm{~ns}$ & $4.49 *$ & $-9.38 \mathrm{~ns}$ & $8.18^{*}$ \\
\hline aa & $-27.17 \mathrm{~ns}$ & - & $6.36 \mathrm{~ns}$ & - & $-2.37 \mathrm{~ns}$ & - \\
\hline $\mathrm{ad}$ & $24.16 \mathrm{~ns}$ & - & $1.98 \mathrm{~ns}$ & - & $0.30 \mathrm{~ns}$ & - \\
\hline $\mathrm{dd}$ & $51.73 \mathrm{~ns}$ & - & $-19.53 \mathrm{~ns}$ & - & $19.02 *$ & - \\
\hline \multicolumn{7}{|c|}{ UFU-Lisa-124\#2\#1 x UFU-Albina\#3 } \\
\hline $\mathrm{m}$ & $0.54 \mathrm{~ns}$ & $28.90^{*}$ & $12.22 *$ & $27.35^{*}$ & $5.09 \mathrm{~ns}$ & $24.43^{*}$ \\
\hline $\mathrm{a}$ & $-5.38 \mathrm{~ns}$ & $-3.31 \mathrm{~ns}$ & $-0.44 \mathrm{~ns}$ & $-0.75 \mathrm{~ns}$ & $-4.55 \mathrm{~ns}$ & $-5.49 \mathrm{~ns}$ \\
\hline $\mathrm{d}$ & $81.69 \mathrm{~ns}$ & $7.17 *$ & $38.95^{*}$ & $3.04 *$ & $49.13 *$ & $3.93 *$ \\
\hline aa & $27.31 \mathrm{~ns}$ & - & $15.05^{*}$ & - & $19.33^{*}$ & - \\
\hline $\mathrm{ad}$ & $20.64 \mathrm{~ns}$ & - & $-3.19 n s$ & - & $-9.38 \mathrm{~ns}$ & - \\
\hline $\mathrm{dd}$ & $-48.25 \mathrm{~ns}$ & - & $-20.93 \mathrm{~ns}$ & - & $-25.87 \mathrm{~ns}$ & - \\
\hline
\end{tabular}

$\mathrm{m}$ : average of all possible homozygous genes; a: average of additive effects; d: measure of the dominance deviations; aa: average of all additive $\mathrm{x}$ additive interactions; ad: average of all additive $\mathrm{x}$ dominant interactions; dd: average of all dominant $\mathrm{x}$ dominant interactions; Chlorop. content $=$ chlorophyll content; ${ }^{*}$ significant at $95 \%$ of confidence; ns $=$ not significant; CM: complete model; ADM: additive-dominant model. 
A. H. G. OLIVEIRA et al.

Table 4. Continuation.

\begin{tabular}{|c|c|c|c|c|c|c|}
\hline \multirow{2}{*}{ Parameters } & \multicolumn{2}{|c|}{ Chlorop. content } & \multicolumn{2}{|c|}{ Plant diameter } & \multicolumn{2}{|c|}{ Number of leaves } \\
\hline & $\mathrm{CM}$ & $\mathrm{ADM}$ & $\mathrm{CM}$ & $\mathrm{ADM}$ & $\mathrm{CM}$ & ADM \\
\hline \multicolumn{7}{|c|}{ UFU-Crespa199\#1\#1 x UFU-Albina\#3 } \\
\hline $\mathrm{m}$ & $35.25 *$ & $32.97^{*}$ & $4.56 \mathrm{~ns}$ & $27.95^{*}$ & $-4.59 \mathrm{~ns}$ & $19.44^{*}$ \\
\hline a & $-10.27 \mathrm{~ns}$ & $-10.29 \mathrm{~ns}$ & $-1.64 n s$ & $-1.73 \mathrm{~ns}$ & $-0.82 \mathrm{~ns}$ & $-0.75 \mathrm{~ns}$ \\
\hline $\mathrm{d}$ & $13.54 \mathrm{~ns}$ & $41.11^{*}$ & $54.28^{*}$ & $-0.64 n s$ & $60.26^{*}$ & $1.95^{*}$ \\
\hline aa & $-2.50 \mathrm{~ns}$ & - & $23.92 *$ & - & $25.29 *$ & - \\
\hline $\mathrm{ad}$ & $6.35 \mathrm{~ns}$ & - & $7.39 \mathrm{~ns}$ & - & $8.58 *$ & - \\
\hline $\mathrm{dd}$ & $-7.69 \mathrm{~ns}$ & - & $-24.34 \mathrm{~ns}$ & - & $-29.97 \mathrm{~ns}$ & - \\
\hline
\end{tabular}

$\mathrm{m}$ : average of all possible homozygous genes; a: average of additive effects; $\mathrm{d}$ : measure of the dominance deviations; aa: average of all additive $\mathrm{x}$ additive interactions; ad: average of all additive $\mathrm{x}$ dominant interactions; dd: average of all dominant $\mathrm{x}$ dominant interactions; Chlorop. content $=$ chlorophyll content; ${ }^{*}$ significant at $95 \%$ of confidence; ns $=$ not significant; CM: complete model; ADM: additive-dominant model.

However, it is important to evaluate the fits of averages to the additive-dominant model and not only to the complete model. Thus, the medium effect (m) was significant for all variables in all the populations evaluated. For the additive-dominant model, the additivity effect was significant only for the variable plant diameter in the cross UFU-Lisa217\#5\#2 x UFU-Albina\#3. The dominance effect was not significant in the performance of plant diameter for the crosses UFU-Lisa-124\#2\#1 x UFUAlbina\#2 and UFU-Crespa199\#1\#1 x UFUAlbina\#3, and chlorophyll content for the cross UFU -Lisa-217\#5\#2 x UFU-Albina\#3 (Table 4).
The most important genetic effect to the content of chlorophyll (SPAD) was due to the additivity for all crosses assessed, explaining 70.14, $59.64,87.94,26.07$ and $92.05 \%$ of all the existing variability in $F_{2}$ (Table 5). The medium effect (m) was the second effect in order of importance for the determination of the content of chlorophyll (SPAD), with the exception of the cross UFU-Lisa-124\#2\#1 $\mathrm{x}$ UFU-Albina\#3, in which the medium effect was equal to zero. This result, according to Cruz, Regazzi and Carneiro (2012), makes it feasible to obtain superior genotypes from the selection in populations derived from these crosses, since the additive nature of the characters is the most important.

Table 5. Coefficient of determination $\left(\mathrm{R}^{2} \%\right.$ ) by non-orthogonal decomposition of the sum of squares of parameters fitted to the complete model $(\mathrm{CM})$ and additive-dominant model $(\mathrm{ADM})$, for agronomic traits, the complete model ( $\mathrm{m}$, a, $\mathrm{d}$, aa, ad, $\mathrm{dd}$ ), of the generations $\mathrm{P}_{1}, \mathrm{P}_{2}, \mathrm{~F}_{1}, \mathrm{~F}_{2}, \mathrm{Bc}_{1}$ and $\mathrm{Bc}_{2}$ of Lactuca sativa.

\begin{tabular}{|c|c|c|c|c|c|c|}
\hline \multirow{2}{*}{ Parameters } & \multicolumn{2}{|c|}{ Chlorop. content } & \multicolumn{2}{|c|}{ Plant diameter } & \multicolumn{2}{|c|}{ Number of leaves } \\
\hline & $\mathrm{CM}$ & ADM & $\mathrm{CM}$ & ADM & $\mathrm{CM}$ & $\mathrm{ADM}$ \\
\hline \multicolumn{7}{|c|}{ UFU-Lisa-217\#5\#2 x UFU-Albina\#2 } \\
\hline a & 70.14 & 12.08 & 10.14 & 0.84 & 93.38 & 15.70 \\
\hline $\mathrm{d}$ & 2.24 & 0.93 & 4.86 & 1.25 & 0.00 & 1.00 \\
\hline Subtotal & 94.11 & 100.00 & 84.81 & 100.00 & 99.26 & 99.99 \\
\hline $\mathrm{ad}$ & 0.14 & - & 0.01 & - & 0.58 & - \\
\hline $\mathrm{dd}$ & 2.62 & - & 3.89 & - & 0.14 & - \\
\hline Epistatic effects & 5.89 & - & 15.19 & - & 0.74 & - \\
\hline \multicolumn{7}{|c|}{ UFU-Lisa-124\#2\#1 x UFU-Albina\#2 } \\
\hline $\mathrm{m}$ & 32.94 & 88.37 & 3.92 & 95.06 & 0.07 & 84.02 \\
\hline ad & 1.59 & - & 7.13 & - & 7.70 & - \\
\hline dd & 1.76 & - & 5.30 & - & 1.59 & - \\
\hline Epistatic effects & 5.94 & - & 27.19 & - & 17.05 & - \\
\hline
\end{tabular}


A. H. G. OLIVEIRA et al.

Table 5. Continuation.

\begin{tabular}{|c|c|c|c|c|c|c|}
\hline \multirow{2}{*}{ Parameters } & \multicolumn{2}{|c|}{ Chlorop. content } & \multicolumn{2}{|c|}{ Plant diameter } & \multicolumn{2}{|c|}{ Number of leaves } \\
\hline & $\mathrm{CM}$ & ADM & $\mathrm{CM}$ & ADM & $\mathrm{CM}$ & ADM \\
\hline \multicolumn{7}{|c|}{ UFU-Lisa-217\#5\#2 x UFU-Albina\#3 } \\
\hline $\mathrm{m}$ & 6.82 & 92.26 & 17.55 & 98.73 & 27.06 & 94.23 \\
\hline $\mathrm{a}$ & 87.94 & 5.60 & 70.13 & 0.50 & 69.03 & 3.68 \\
\hline $\mathrm{d}$ & 1.11 & 2.14 & 4.98 & 0.77 & 0.37 & 2.09 \\
\hline Subtotal & 95.87 & 100.00 & 92.66 & 100.00 & 96.46 & 100.00 \\
\hline aa & 1.51 & - & 2.11 & - & 0.20 & - \\
\hline ad & 1.24 & - & 0.21 & - & 0.00 & - \\
\hline dd & 1.37 & - & 5.01 & - & 3.33 & - \\
\hline Epistatic effects & 4.12 & - & 7.33 & - & 3.53 & - \\
\hline \multicolumn{7}{|c|}{ UFU-Lisa-124\#2\#1 x UFU-Albina\#3 } \\
\hline $\mathrm{m}$ & 0.00 & 96.95 & 17.04 & 99.56 & 1.10 & 94.38 \\
\hline $\mathrm{a}$ & 26.07 & 1.31 & 1.07 & 0.08 & 43.02 & 4.91 \\
\hline d & 21.26 & 1.74 & 29.97 & 0.36 & 17.71 & 0.71 \\
\hline Subtotal & 47.33 & 100.00 & 48.08 & 100.00 & 61.83 & 100.00 \\
\hline aa & 14.01 & - & 26.39 & - & 16.17 & - \\
\hline ad & 19.21 & - & 2.84 & - & 9.14 & - \\
\hline $\mathrm{dd}$ & 19.44 & - & 22.68 & - & 12.87 & - \\
\hline Epistatic effects & 52.66 & - & 54.91 & - & 38.18 & - \\
\hline \multicolumn{7}{|c|}{ UFU-Crespa199\#1\#1 x UFU-Albina\#3 } \\
\hline $\mathrm{m}$ & 7.27 & 89.79 & 1.20 & 99.61 & 1.40 & 99.63 \\
\hline $\mathrm{a}$ & 92.05 & 8.88 & 33.70 & 0.38 & 6.59 & 0.13 \\
\hline $\mathrm{d}$ & 0.15 & 1.33 & 19.78 & 0.00 & 28.19 & 0.24 \\
\hline Subtotal & 99.47 & 100.00 & 54.68 & 99.99 & 36.18 & 100.00 \\
\hline aa & 0.04 & - & 33.27 & - & 42.92 & - \\
\hline ad & 0.38 & - & 3.41 & - & 5.26 & - \\
\hline dd & 0.11 & - & 8.63 & - & 15.62 & - \\
\hline Epistatic effects & 0.53 & - & 45.31 & - & 63.80 & - \\
\hline
\end{tabular}

Generally, the simple effects $(m, a, d)$ for the chlorophyll content (SPAD) explain a great part of the variability. However, for the cross UFU-Lisa124\#2\#1 x UFU-Albina\#3 the epistatic interactions additive $\mathrm{x}$ additive (aa), additive $\mathrm{x}$ dominant $(\mathrm{ad})$ and dominant $\mathrm{x}$ dominant $(\mathrm{dd})$ had relatively high $\mathrm{R}^{2}$ (14.01; 19.21 and 19.44, respectively), when compared to the $\mathrm{R}^{2}$ of the additive gene effect (26.07).

For the variable numbers of leaves, the additive effect assumes great importance in the crosses UFU-Lisa-217\#5\#2 x UFU-Albina\#2, UFULisa-124\#2\#1 x UFU-Albina\#2, UFU-Lisa-217\#5\#2 $x$ UFU-Albina\#3 and UFU-Lisa-124\#2\#1 x UFUAlbina\#3, explaining 93.38, 79.15, 69.03 and 43.02, respectively, while for the crosses UFUCrespa199\#1\#1 x UFU-Albina\#3 the greatest importance is attributed to the effect of dominance.

Evaluating the additive-dominant model, the $\mathrm{m}$ effect explained most of the results of the $F_{2}$ generation. However, the effect of additivity explained a maximum of 12.08 and $15.70 \%$ of the variables chlorophyll content and number of leaves, respectively, in the cross UFU-Lisa-217\#5\#2 x UFUAlbina\#2, and $4.94 \%$ of the variability of plant diameter in the cross UFU-Lisa-124\#2\#1 x UFUAlbina\#2.
The additive-dominant model was not sufficient to explain all the data in this study. The correlation between the averages observed and expected (Figure 1) indicated a satisfactory fit to the complete model for the variable chlorophyll content (SPAD) of the crosses UFU-Lisa-217\#5\#2 x UFUAlbina\#2, UFU-Lisa-124\#2\#1 x UFU-Albina\#2 and UFU-Crespa199\#1\#1 x UFU-Albina\#3 ( $\mathrm{r}=0.96$; 0.97 and 0.95 , respectively).

After analyzing pigments and agronomic characters in just one hybridization, Oliveira et al. (2019) also observed a greater importance of additive effects in four characteristics evaluated for all variability in $\mathrm{F}_{2}$. Additionally, it is important to emphasize that, under these conditions, it is possible to obtain superior homozygous genotypes in $F_{2}$ (MOREIRA et al., 2013; OLIVEIRA et al., 2019) being fundamental to the success of lettuce breeding programs.

For the variable number of leaves, the data only showed a satisfactory fit to the model for the crosses UFU-Lisa-217\#5\#2 x UFU-Albina\#2 ( $\mathrm{r}=$ 0.98 ) and UFU-Lisa-217\#5\#2 x UFU-Albina\#3 ( $\mathrm{r}=$ 0.93 ), while for plant diameter the fit was considered between low and medium in all crosses evaluated (Figure 1). 
Chlorophyll content

UFU-Lisa-124\#2\#1 x UFU-Albina\#2

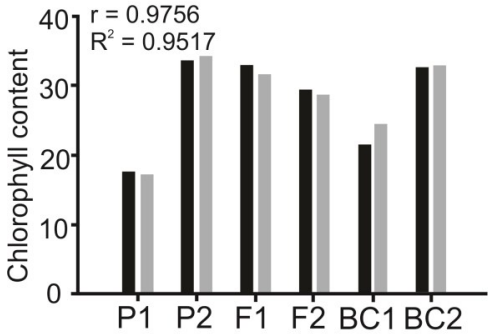

UFU-Lisa-124\#2\#1 x UFU-Albina\#3

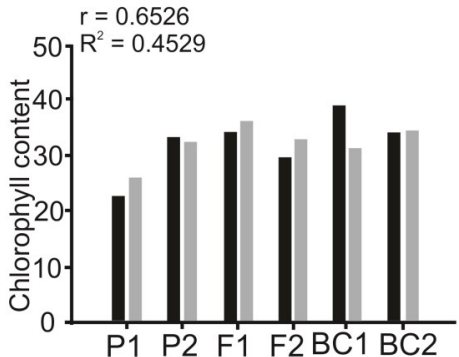

UFU-Crespa-199\#1\#1 x UFU-Albina\#3

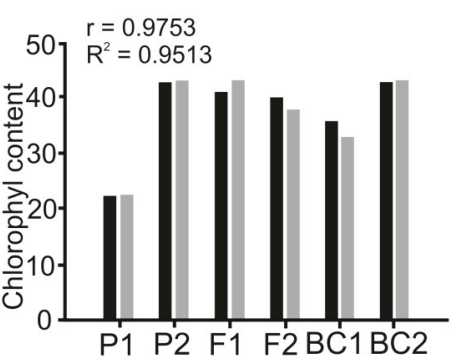

UFU-Lisa-217\#5\#2 x UFU-Albina\#2

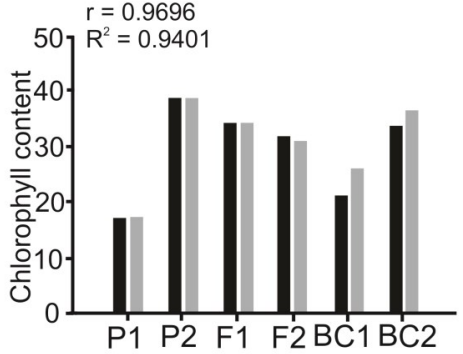

UFU-Lisa-217\#5\#2 x UFU-Albina\#3

$r=0.7191$

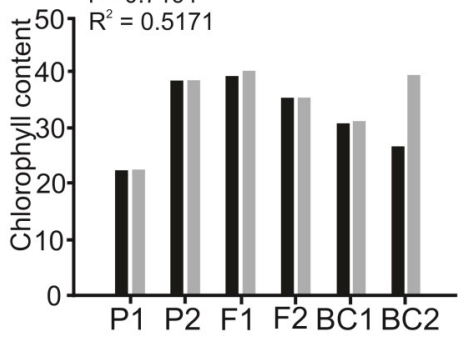

Diameter

UFU-Lisa-124\#2\#1 x UFU-Albina\#2

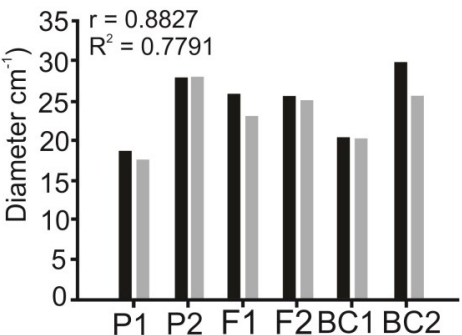

UFU-Lisa-124\#2\#1 x UFU-Albina\#3

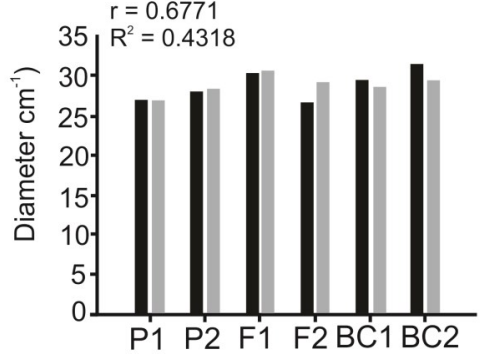

UFU-Crespa-199\#1\#1 x UFU-Albina\#3
Number of leaves

UFU-Lisa-124\#2\#1 x UFU-Albina\#2

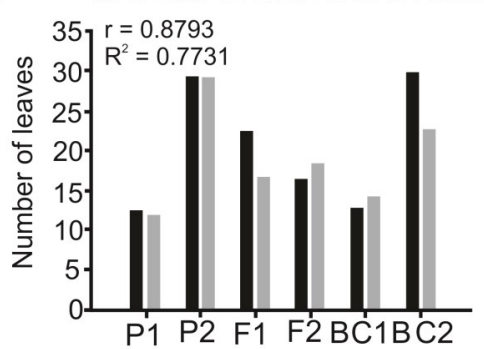

UFU-Lisa-124\#2\#1 x UFU-Albina\#3

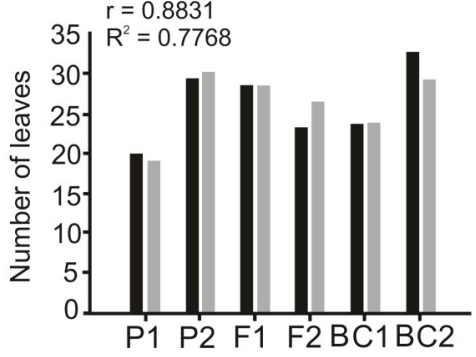

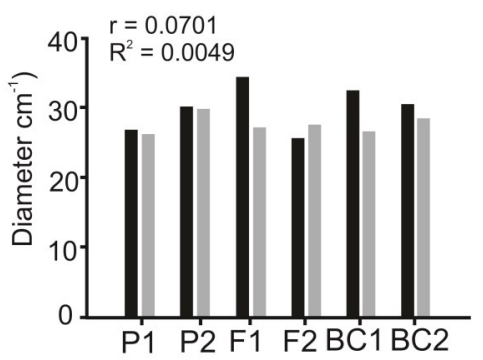

UFU-Lisa-217\#5\#2 x UFU-Albina\#2

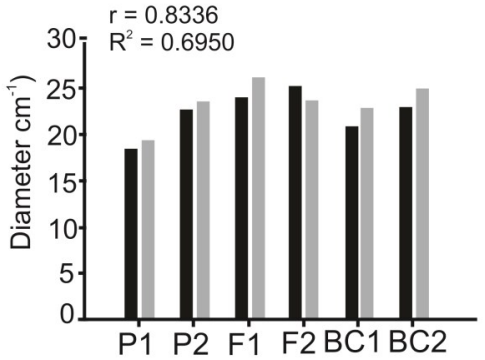

UFU-Lisa-217\#5\#2 x UFU-Albina\#3 $r=0.8121$

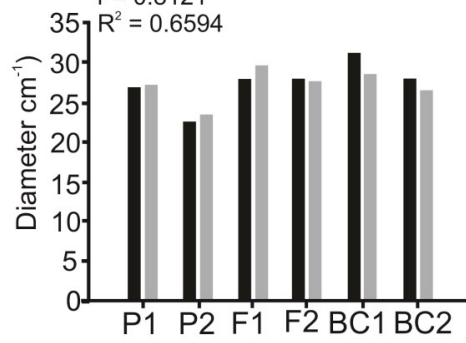

Averages expected

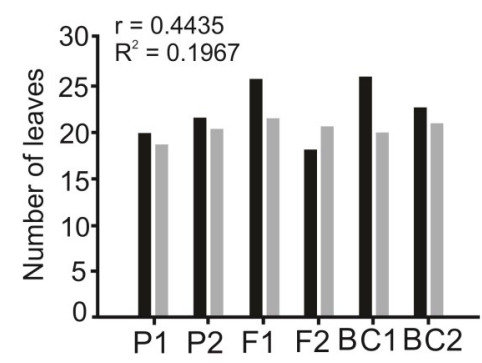

UFU-Lisa-217\#5\#2 x UFU-Albina\#2
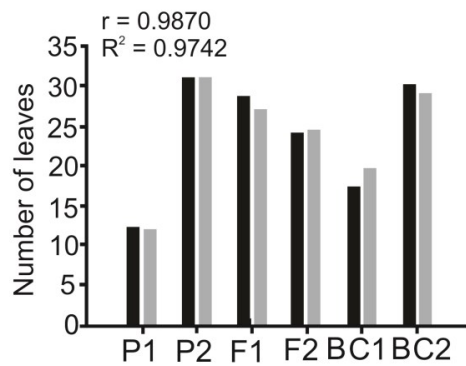

UFU-Lisa-217\#5\#2 x UFU-Albina\#3

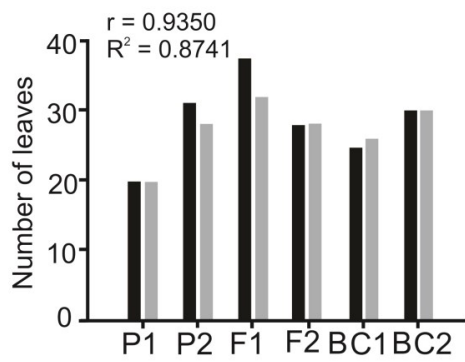

Figure 1. Averages observed and expected for each one of the generations in the additive-dominant model for three agronomic traits of Lactuca sativa. 


\section{CONCLUSIONS}

There is a polygenic or oligogenic pattern for the characteristics number of leaves, plant diameter and chlorophyll content. The gene interaction involved in the expression of plant diameter is predominantly of overdominance and the characteristics of number of leaves and chlorophyll content appear to be of partial dominance. The occurrence of transgressive segregants was observed mainly in the characteristics of plant diameter and chlorophyll content.

\section{ACKNOWLEDGMENTS}

The authors thank the Conselho Nacional de Desenvolvimento Científico e Tecnológico (CNPq), the Coordenação de Aperfeiçoamento de Pessoal de Nível Superior (CAPES) and the Fundação de Amparo à Pesquisa do Estado de Minas Gerais (FAPEMIG).

\section{REFERENCES}

ANDRADE, F. N. et al. Estimativas de parâmetros genéticos em genótipos de feijão-caupi avaliados para feijão fresco. Revista Ciência Agronômica, 41: 253-258, 2010.

AZEVEDO, A. M. et al. Seleção de genótipos de alface para cultivo protegido: divergência genética e importância de caracteres. Horticultura Brasileira, 31: 260-265, 2013.

BALDISSERA, J. N. C. et al. Fatores genéticos relacionados com a herança em populações de plantas autógamas. Revista de Ciências Agroveterinárias, 13: 181-189, 2014.

BENIN, G. et al. Identificação da dissimilaridade genética entre genótipos de feijoeiro comum (Phaseolus vulgaris L.) do grupo preto. Revista Brasileira Agrociência, 8: 179-184, 2002.

BERTAN, I. et al. Dissimilaridade genética entre genótipos de trigo avaliados em cultivo hidropônico sob estresse por alumínio. Bragantia, 65: 55-63, 2006.

BLANK, A. F. et al. Comportamento fenotípico e genotípico de populações de manjericão. Horticultura Brasileira, 28: 305-310, 2010.

BORÉM; A.; MIRANDA, G.V. Melhoramento de Plantas. 5 ed. Viçosa, MG: Editora UFV, 2009. 529 p.
BRZEZINSKI, C. R. et al. Produção de cultivares de alface americana sob dois sistemas de cultivo. Revista Ceres, 64: 83-89, 2017.

CASSETARI, L. S. et al. $\beta$-Carotene and chlorophyll levels in cultivars and breeding lines of lettuce. Acta Horticulturae, 1083: 469-473, 2015.

CORREA, A. M. et al. Estimativas de parâmetros genéticos e correlações entre caracteres fenológicos e morfoagronômicos em feijão-caupi. Revista Ceres, 59: 88-94, 2012.

CRUZ, C. D. Genes: a software package for analysis in experimental statistics and quantitative genetics. Acta Scientiarum Agronomy, 35: 271276,2013

CRUZ, C. D.; REGAZZI, A. J.; CARNEIRO, P. C. $\mathrm{S}$. Modelos biométricos aplicados ao melhoramento genético. 4 ed. Viçosa, MG: Editora UFV, 2012. $514 \mathrm{p}$.

CUSTÓDIO, T. N. et al. Meta-analysis for heritability of estimates development and production traits of Coffea canephora Pierre. Semina: Ciências Agrárias, 33: 2501-2510, 2012.

DIAMANTE, M. S. et al. Production and resistance to bolting of loose-leaf lettuce grown in different environments. Revista Ciência Agronômica, 44: 133-140, 2013.

GOMES, G. P. et al. Registro e proteção de olerícolas no Brasil, período de 1998 a 2014. Horticultura Brasileira, 34: 19-25, 2016.

LAVIOLA, B. G. et al. Desempenho agronômico e ganho genético pela seleção de pinhão-manso em três regiões do Brasil. Pesquisa Agropecuária Brasileira, 49: 356-363, 2014.

MACHADO JUNIOR, R. et al. Vegetable breeding as a strategy of biofortification in carotenoids and prevention of vitamin A deficiency. African Journal of Agricultural Research, 12: 1059-1066, 2017.

MACIEL, G. M. et al. BG $\boldsymbol{\alpha}$ BIOFORT. Registro INPI No: BR512019002403-6. Uberlândia, MG: Universidade Federal de Uberlândia, 2019.

MOREIRA, G. R. et al. Herança de caracteres de resistência por antixenose de Solanum pennellii à traça-do-tomateiro em cruzamento com 'Santa Clara'. Horticultura Brasileira, 31: 574-581, 2013.

OLIVEIRA, A. H. G. et al. Estimates of genetic parameters of pigments and agronomic traits in green and purple lettuce. Ciência e Agrotecnologia, 43: 1- 
8,2019 .

OLIVEIRA, N. S. et al. Seleção e parâmetros genéticos de progênies de coentro tolerantes ao calor. Horticultura Brasileira, 33: 319-323, 2015.

OLIVEIRA, V. C. et al. Agronomic biofortification of carrot with selenium. Ciência e Agrotecnologia, 42: 138-147, 2018.

RESENDE, G. M. et al. Adaptação de genótipos de alface crespa em condições semiáridas. Revista Brasileira de Agricultura Irrigada, 11: 1145-1154, 2017.

SALA, F. C.; COSTA, C. P. Retrospectiva e tendência da alfacicultura brasileira. Horticultura Brasileira, 30: 187-194, 2012.

SILVA, M. A. et al. Pigmentos fotossintéticos e índice Spad como descritores de intensidade do estresse por deficiência hídrica em cana-deaçúcar. Bioscience Journal, 30: 173-181, 2014.

SOUZA, M. C. M. et al. Variabilidade genética para características agronômicas em progênies de alface tolerantes ao calor. Horticultura Brasileira, 26: 354 $-358,2008$.

SUINAGA, F. A. et al. Desempenho produtivo de cultivares de alface crespa. Brasília, DF: Embrapa Hortaliças, 2013. 15 p.

TAIZ, L.; ZEIGER, E. Fisiologia vegetal. 5.ed. Porto Alegre, RS: Artmed, 2013.918 p. 